\title{
Total nitrogen, water-soluble nitrogen and free amino acids profile during ripening of soft cheese enriched with Nigella sativa seed oil
}

\author{
Mara Georgescu ${ }^{1 *}$, Ștefania Mariana Raita ${ }^{2}$ and Dana Tăpăloagă ${ }^{1}$
}

\begin{abstract}
Various antimicrobial solutions have been tested as additives for raw milk traditional cheeses, among which Nigella sativa cold pressed seed oil (NSSO) is recognized for its positive effect on the microbial quality of such products. The overall effect on the quality of enriched cheeses during ripening is still under extensive investigation. Three batches of traditional raw milk brined cheese were included in the current experiment: control cheese without Nigella sativa seed oil (NSSO) and cheese samples enriched with 0.2 and $1 \% \mathrm{w} / \mathrm{w}$ NSSO. Experimental cheese samples were analyzed in duplicates for total nitrogen content (TN), at $0,14,28$ and 42 days of ripening, while single determinations of total nitrogen (WSN) and free amino acids (FAA) were performed at 14, 28 and 42 ripening days. The TN content revealed similar values for control cheeses and NSSO cheeses, and no significant differences were noticed within the three treatment groups $(\mathrm{p}>.05)$ throughout ripening. WSN values followed a significant rising shift in all cheeses during ripening, yet computing data obtained for the three considered treatments, despite an obvious higher WSN content of NSSO enriched cheeses, no statistical significance could be associated to this difference. The FAA composition of the experimental cheeses, varied quantitatively, by increasing with ripening time, but no qualitative variation was noticed during the follow-up period. The FAA composition of the did not vary significantly within treatments.
\end{abstract}

Keywords: Nigella sativa seed oil, soft cheese, ripening indices

'Department of Animal Production and Public Health, University of Agronomical Sciences and Veterinary Medicine of Bucharest, Romania

${ }^{2}$ Department of Preclinical Sciences, University of Agronomical Sciences and Veterinary Medicine of Bucharest, Romania

*Corresponding author: M. Georgescu E-mail: dr_georgescu_mara@yahoo.com

DOI: 10.2478/ebtj-2019-0010

\section{Introduction}

Many aspects concerning the versatility and amazing diversity of traditional cheeses characteristics, depending on the manufacturing and conditioning, are not yet completely understood. The trend in international scientific world is to understand the composition and dynamics peculiarities concerning the physicochemical, biochemical and microbiological changes that take place in raw milk cheeses during manufacturing, ripening and storing (1-3).

As extensive literature reports, raw milk traditional cheeses are not always safe, being associated with food borne infections or intoxications (4-9). If most hard or semi-hard raw milk cheeses are usually ripened long enough to be safe for consumption, traditional soft cheeses continue to be a real hazard for public safety, as they provide appropriate environment for pathogens survival and development $(10,11)$. A continuous search of antimicrobial solutions, adequate as natural additives in foods in general and in cheeses, in particular, has increasingly been reported by recent studies (12-17). Enrichment of cheeses with Nigella sativa seed oil (NSSO) has been studied by several authors, mostly for its antimicrobial properties (18-22).

However, the effect of NSSO on the ripening indices has not been sufficiently studied, as each type of cheese is considered a unique biochemical system and the specificity of each assortment should be considered when performing investigations on influences on ripening depth and extent. Previous studies on $0.1 \% \mathrm{w} / \mathrm{w}$ NSSO cheese and $0.2 \% \mathrm{w} / \mathrm{w}$ 
NSSO cheese indicated no significant influence on some of the ripening indices (such as total nitrogen, expressed as protein content) (23), revealed positive effect on the sensory parameters under panel studies (24) but did not explore more significant ripening indices, such as water soluble nitrogen (WSN), or free amino acid (FAA) content.

It is widely accepted that in hard cheeses, the development of proteolysis is associated with an increase of water-soluble nitrogen (SN) as a percentage of total nitrogen (TN), but the characterization of proteolysis for each particular cheese must consider the peculiarities which govern the formation of peptides and FAA (25).

The present study aims to extend the knowledge on NSSO enrichment effect on raw milk soft cheese, using higher concentrations of NSSO, than the ones of previous studies and further investigate how NSSO is affecting cheese ripening profiling, by studying more specific ripening indices, such as total nitrogen (TN), water soluble nitrogen (WSN).

\section{Material and Methods}

Recent Fresh raw bovine milk was collected from small local farms and one collection center in Argeș county, Romania, and delivered to the traditional processing facility where the experimental brined Telemea cheese was obtained. Powder bovine rennet Ideal ${ }^{\circ}$ was obtained from Ideal Still Exim SRL (Chitila, Romania) and was used as water solution according to the manufacturer indications. Nigella sativa (black cumin) cold pressed seed oil (Negriol) was purchased from a Romanian company, Aghoras Invent SRL, Bucharest.

\section{Manufacture of cheese}

For experimental cheese production, milk received at processing unit was checked for titratable acidity (between $16-19^{\circ} \mathrm{T}$ ), fat content and temperature $\left(4-8^{\circ} \mathrm{C}\right)$. The fat content of raw milk was variable (3-5.5\%, with an average of $3.8 \%$ ) and is usually not adjusted in this traditional cheese manufacture, leading to a natural fat content variation in cheese. For experimental purposes, fat content of raw milk was standardized to $4 \%$, leading to $45 \%$ fat in dry matter (\%FDM) in final product. The average experimental cheese yield from milk was 12-15/100 l. Milk was received refrigerated $\left(4-8^{\circ} \mathrm{C}\right)$ and heated mildly at $30-35^{\circ} \mathrm{C}$. No starter culture was used before curdling and there was no addition of calcium chloride, as traditional cheese making is using raw, un-pasteurized milk, with natural lactic acid bacteria. The experiment included three batches of cheese: control cheese without NSSO, $0.2 \% \mathrm{w} / \mathrm{w}$ NSSO enriched cheeses and $1 \% \mathrm{w} / \mathrm{w}$ NSSO enriched cheeses. The NSSO was added to the mildly heated milk in the respective concentrations, before renneting. The content of the Ideal ${ }^{\circ}$ rennet dose $(8 \mathrm{~g})$ was diluted in $250 \mathrm{ml}$ warm distilled water and $25 \mathrm{ml}$ solution were added to 101 warm milk $\left(30-35^{\circ} \mathrm{C}\right)$, under continuous manual mixing for 10 minutes. Coagulation time was $30-45$ minutes. The soft curd was left for further solidification needed for processing, for 15-30 minutes. Further stages of the technological process were followed according to the usual, traditional Romanian soft brined cheese manufacturing (26). The soft curd is processed through repeated pressing and cutting into pieces (Fig.1) until left resting for 20 minutes before cutting to final size cubes $(12 / 12 \mathrm{~cm})$. The brine concentration used for experimental cheese was $6-8 \%$. Brining was performed at maximum $16^{\circ} \mathrm{C}$, for 24 hours and was followed by drying for 12 hours at $2-8^{\circ} \mathrm{C}$ on wood shelves. Experimental cheese was packed in vacuumed plastic bags and kept refrigerated $\left(4-8^{\circ} \mathrm{C}\right)$ for 42 days.

\section{Chemical analysis}

Total nitrogen (TN). Experimental cheese samples were analyzed in duplicates for protein content (Total nitrogen - TN), at 0 , $14,28,35$ and 42 days of ripening, according to the AOAC Official Method of Analysis - Method 33.7.12A (27). The protein content was obtained by multiplying the percentage of TN, by 6.38 (per $100 \mathrm{~g}$ cheese). Ripening indices were analyzed without repetitions, at 14, 28 and 42 days of ripening: the contents of water-soluble nitrogen (WSN) and determination of free amino acids (FAA):

Water soluble nitrogen (WSN). Determination of water-soluble nitrogen (WSN) was performed according to the method described by Kuchroo and Fox (28). The water-soluble extract was prepared by homogenizing $4 \mathrm{~g}$ grated cheese in a stomacher with water at $50^{\circ} \mathrm{C}$, for about 10 minutes, until a homogeneous sample was obtained. Some authors communicated that the level of extractable $\mathrm{N}$ increases with the ratio of water to cheese but recommend a ratio of 2:1 (29). In our procedure, the resulted paste was diluted with distilled water to $100 \mathrm{ml}$. The slurry was held at $40^{\circ} \mathrm{C}$ for $1 \mathrm{~h}$, centrifuged and the supernatant filtered through Whatman no 113-filter paper. Only one extraction was performed (the residue was not re-extracted). The filtered homogenate was analyzed for WSN by Kjeldahl method (AOAC Official Method of Analysis - Method 33.7.12A) and was expressed as $\%$ of TN.

Determination of free amino acids (FAA). The EZ:faast ${ }^{\mathrm{TM}}$ amino acid analysis was used for determination of FAA in the experimental cheese samples. The EZ:faast ${ }^{\mathrm{TM}}$ amino acid analysis procedure consists in a solid phase extraction step, followed by derivatization and liquid/liquid extraction. Derivatized samples are quickly analyzed by gas chromatography with FID (flame ionization detector). The solid phase extraction is performed via a sorbent packed tip that binds amino acids, while allowing interfering compounds to flow through. Amino acids on sorbent are then extruded into the sample via land quickly derivatized with reagent at room temperature in aqueous solution. Derivatized amino acids concomitantly migrate to the organic layer for additional separation from interfering compounds. An aliquot from the organic is analyzed on a Hewlett Packard GC system with FID. The GC settings used for the FAA determination involved 1:15 split rate, at $250^{\circ} \mathrm{C}$, for $1.5-2 \mu \mathrm{l}$; the carrier gas was helium, with a column flow rate of $1.5 \mathrm{ml} / \mathrm{min}$, constant flow. Both injector and detector temperature were $320^{\circ} \mathrm{C}$. The column temperature ranged from 110 to $320^{\circ} \mathrm{C}$, with a $32^{\circ} \mathrm{C} / \mathrm{min}$ rate. The total FAA content of the sample is calculated as follows: 


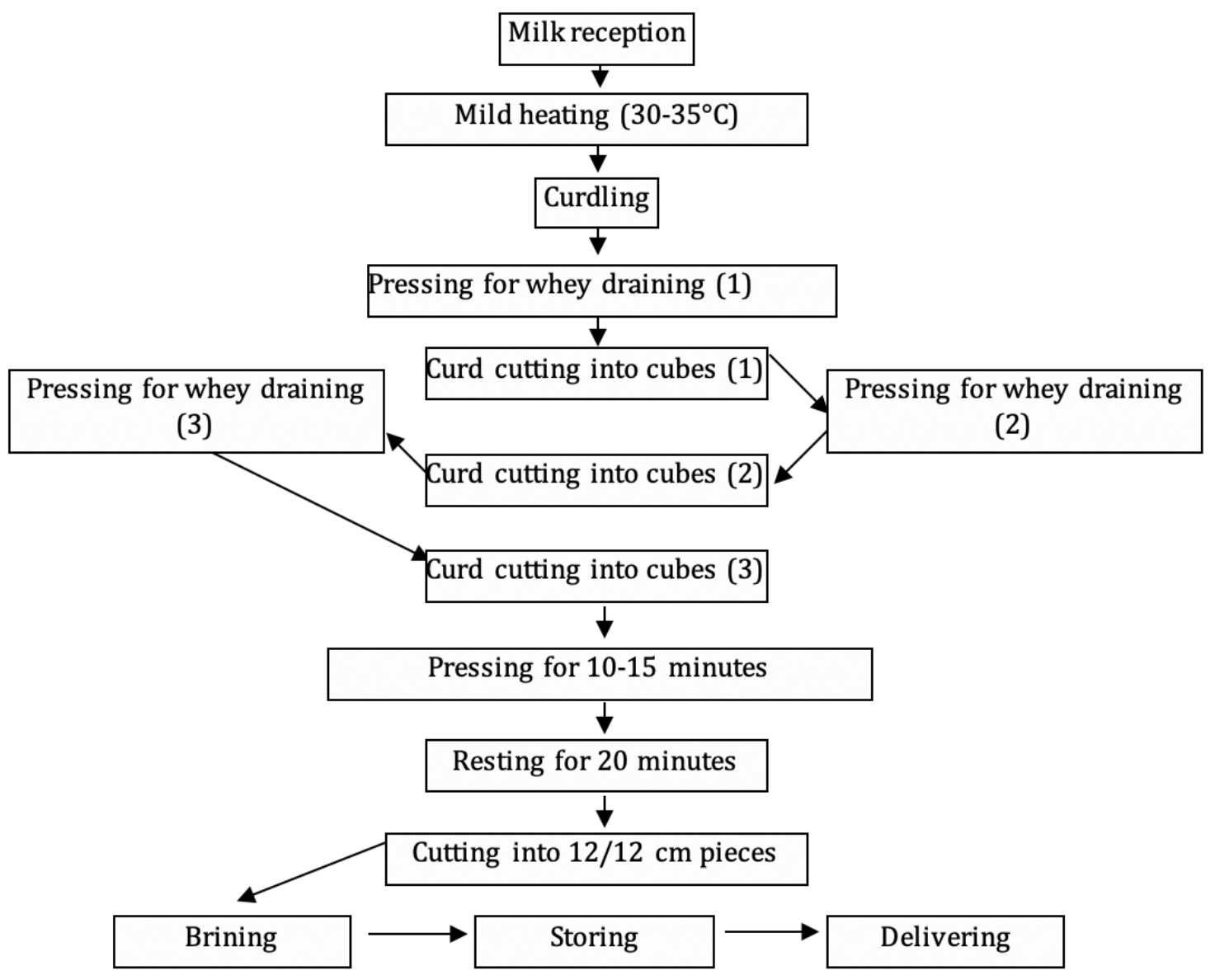

Figure 1. Traditional Romanian soft brined cheese manufacture diagram.

Total FAA (nmole) $=\mathrm{GC}$ printout value $(\mathrm{nmole} / 100 \mu \mathrm{l}) \mathrm{x}$ 1000 (dilution factor)

$\% \mathrm{FAA}=[($ total FAA, nmole $\times \mathrm{M}$ amino acid $) /$ sample weight, ng] $\times 100$,

Where M - molar weight of a particular amino acid.

\section{Data analysis}

The study design included the three batches of cheese samples: control cheese (without NSSO) - batch 1 (B1), 0.2\% w/w NSSO enriched cheese - batch 2 (B2), 1\% w/w NSSO enriched cheese - batch 3 (B3). The three batches of cheese were considered the three treatments, which were analyzed at $0,14,28$ and 42 days of ripening. Each sample was analyzed in triplicates for TN and WSN and no repetition for FAA. Variance analysis of data was performed by One-way analysis of variance (ANOVA) using SAS (30). The threshold of significance level between treatments was $\mathrm{p}<0.05$.

\section{Results}

\section{Total nitrogen (TN) content of experimental cheese}

The TN content of analyzed cheeses did not show significant increase during ripening. Considering the four ripening periods as treatment groups, data analysis revealed no significant differences between these groups (f-ratio value $=1.32612$; $\mathrm{p}$-value $=0.283063)$.

However, TN content revealed significant differences within the three treatment groups ( $\mathrm{f}$-ratio value $=59.34644$; The $\mathrm{p}$-value is $<0.00001$; The result is significant at $\mathrm{p}<0.05$ ), as slightly higher values were associated with NSSO enriched cheeses, compared with control cheese batch. At the end of the ripening period, TN value averaged $2.29 \pm 0.01$ for $1 \% \mathrm{w} / \mathrm{w}$ NSSO cheese batch, compared with $2.15 \pm 0.03$ for control cheese batch (Table 1).

Water soluble nitrogen (WSN) content of experimental cheese WSN values followed a rising shift in all cheeses during ripening (table 1). Considering the four ripening periods as treatments, there was a significant higher set of WSN values as the cheese progressed in ripening period ( $\mathrm{f}$-ratio value $=$ 175.73939; $\mathrm{p}$-value is <.00001; The result is significant at $\mathrm{p}<$ 0.05.), unlike the trend in $\mathrm{TN}$, which did not show the same type of variation.

Computing data obtained for the three considered treatments (control, batch 1 , with $0.2 \% \mathrm{w} / \mathrm{w}$ NSSO and batch 2 , with $1 \% \mathrm{w} / \mathrm{w}$ NSSO), despite an obvious higher WSN content of NSSO enriched cheeses (table 1), no statistical significance could be associated to this difference ( $\mathrm{f}$-ratio value $=0.69678$; The p-value is 0.50537 ). 
Table 1. Total Nitrogen (TN) and Water Soluble Nitrogen (WSN) in experimental cheeses during 42 days of ripening

\begin{tabular}{|l|l|l|l|}
$\begin{array}{l}\text { Experimental cheese batch } \\
\text { (treatments) }\end{array}$ & Ripening time (days) & $\begin{array}{l}\text { Total nitrogen (TN, \%) } \pm \text { St. } \\
\text { dev }\end{array}$ & $\begin{array}{l}\text { Water soluble nitrogen } \\
\text { (WSN, \%) } \pm \text { St. dev }\end{array}$ \\
\hline Control (no NSSO) & 0 & $2.08 \pm 0.02$ & $2.94 \pm 0.035$ \\
\hline Batch 1 (0.2\% w/w NSSO) & 0 & $2.14 \pm 0.03$ & $6.16 \pm 0.065$ \\
& 42 & $2.14 \pm 0.015$ & $11.14 \pm 0.015$ \\
\hline Batch 2 (1\% w/w NSSO) & 14 & $2.15 \pm 0.03$ & $16.14 \pm 0.09$ \\
\hline & 0 & $2.15 \pm 0.015$ & $2.84 \pm 0.0575$ \\
\hline & 42 & $2.19 \pm 0.015$ & $7.18 \pm 0.015$ \\
\hline & 14 & $2.19 \pm 0.036$ & $12.23 \pm 0.03$ \\
\hline & 28 & $2.20 \pm 0.04$ & $18.47 \pm 0.02$ \\
\hline & 42 & $2.24 \pm 0.02$ & $3.27 \pm 0.02$ \\
\hline
\end{tabular}

\section{Free amino acid (FAA) content of experimental cheese}

The FAA composition of the experimental cheeses considered for this study, varied quantitatively, by increasing with ripening time. No qualitative variation was noticed during the 42 days of experimental follow-up. The FAA composition of the three treatment experimental cheeses did not vary significantly for day 14 of ripening (The f-ratio value is 0.52757 ; The p-value is 0.591563 ). The total FAA content of cheeses at 14 days of ripening showed little variance between treatments: 27,1471 $\mathrm{mg} / 100 \mathrm{~g}$ for control batch, $27,2269 \mathrm{mg} / 100 \mathrm{~g}$ for the $0.2 \% \mathrm{w} / \mathrm{w}$ NSSO batch and a slightly higher content, of $35,5764 \mathrm{mg} / 100 \mathrm{~g}$, for the $1 \% \mathrm{w} / \mathrm{w}$ NSSO batch. Despite the obvious difference in FAA amount between batch 1 and 2, no significance was associated to the difference of values for all considered FAA $(\mathrm{p}<0.5)$. Similarly, no significant difference was noticed between the three treatments, at 28-day ripening (The f-ratio value is 0.36784 ; The $\mathrm{p}$-value is 0.693055$)$, nor at 42 days of ripening (The f-ratio value is 0.22976 ; The $\mathrm{p}$-value is 0.795112 ). Despite the lack of statistical significance, there was an obvious quantitative variance of the total FAA at 42 days of ripening, between the three treatment groups, as the total amount of FAA was higher with $8.75 \mathrm{mg} / 100 \mathrm{~g}$ for batch 2 , compared with control. This difference was marking even when comparing the total FAA values of control and batch 2 , at 28 days of ripening: $30.94 \mathrm{mg} / 100 \mathrm{~g}$ for the control batch, compared with 43.97 $\mathrm{mg} / 100 \mathrm{~g}$, for batch 2 .

The amount of FAA did increase with ripening time, as shown by total amount FAA at the three ripening moments considered, for all the treatments: $7.23 \mathrm{mg} / 100 \mathrm{~g}$ increase during ripening time, for control cheeses, $2.35 \mathrm{mg} / 100 \mathrm{~g}$ for batch 1 and $7.56 \mathrm{mg} / 100 \mathrm{~g}$ for batch 2 . However, no statistical significance could be associated with this FAA rising shift variance during ripening, for the experimental brined cheese considered (Table 2). Also, the increasing rate difference between treatments was low and inconsistent with the amount of NSSO added to the cheeses.

\section{Discussions}

Proteolytic reactions that occur during cheese manufacture and ripening are seen as major contributors to texture and flavor development (31). Primary proteolysis in cheese consist in the degradation of casein into large polypeptides, in the initial phases of ripening (32).

\section{TN content of experimental cheeses}

Our results indicate that TN content does not vary significantly with ripening, but shows significant differences within the treatment groups, as slightly higher values are associated with NSSO enriched cheeses $(\mathrm{p}<0.5)$.

The higher values of TN content of NSSO enriched samples, compared to control suggest a positive influence of NSSO on cheese proteolysis. This is also cited in literature, some studies implying that NSSO association with more intense proteolysis leads to the formation of aldehydes, ketones and other miscellaneous compounds (22), which correlate to a higher acceptance of these cheeses to consumers.

Previous studies of the physicochemical properties of NSSO enriched cheeses $(23)$ revealed no significant $(p>0.05)$ differences between treated cheeses and control, even though data indicates slightly higher proteolysis after 42 days of ripening which were consistent with better sensory grades reported by similar research (24), in cheeses enriched with NSSO. These results indicate that $0.1-0.2 \% \mathrm{w} / \mathrm{w}$ NSSO (lower concentrations than the ones used by the present study) does not interfere in 
Table 2. FAA content $(\mathrm{mg} / 100 \mathrm{~g})$ in experimental cheeses during 42 days of ripening

\begin{tabular}{|c|c|c|c|c|c|c|c|c|c|c|c|}
\hline \multirow{2}{*}{ No. } & \multirow{2}{*}{\multicolumn{2}{|c|}{ Amino acid }} & \multicolumn{3}{|l|}{ Control } & \multicolumn{3}{|c|}{ Batch $1(0.2 \%)$} & \multicolumn{3}{|c|}{ Batch $2(1 \%)$} \\
\hline & & & 14d & 28d & $42 d$ & $14 d$ & $28 d$ & $42 d$ & $14 d$ & $28 d$ & $42 d$ \\
\hline 1. & Alanine & ALA & 0,8116 & 0,9817 & 1,1216 & 0,8169 & 0,7955 & 1,0806 & 1,1341 & 1,2321 & 1,3292 \\
\hline 2. & Glycine & GLY & 0,4034 & 0,4907 & 0,6533 & 0,4406 & 0,4535 & 0,667 & 0,7012 & 0,6434 & 0,6123 \\
\hline 3. & Valine & VAL & 1,1152 & 1,5311 & 1,5674 & 1,1527 & 1,1 & 1,3765 & 1,599 & 1,8087 & 1,5733 \\
\hline 4. & Leucine & LEU & 2,3809 & 2,3612 & 2,8767 & 2,3691 & 2,1854 & 2,7351 & 3,0473 & 3,5025 & 3,5694 \\
\hline 5. & Isoleucine & ILE & 0,9353 & 1,0625 & 1,2199 & 0,913 & 0,8579 & 1,073 & 1,1438 & 1,5951 & 1,4429 \\
\hline 6. & Threonine & THR & 1,4032 & 1,3865 & 2,2382 & 1,1888 & 1,2864 & 1,6259 & 1,2019 & 1,8737 & 1,6152 \\
\hline 7. & Serine & SER & 1,1938 & 1,426 & 1,6509 & 0,7041 & 1,0298 & 0,8133 & 1,2537 & 1,3987 & 1,4008 \\
\hline 8. & Proline & PRO & 2,5432 & 2,869 & 3,706 & 2,6537 & 2,77 & 3,7163 & 3,7256 & 4,3507 & 3,5816 \\
\hline 9. & Aspartic acid & ASP & 1,7103 & 2,2 & 2,5568 & 1,6743 & 1,8607 & 2,4809 & 3,1145 & 3,2463 & 2,8177 \\
\hline 10. & Methionine & MET & 0,7937 & 0,849 & 0,9967 & 0,7997 & 0,74 & 1,0683 & 0,9832 & 1,0952 & 1,119 \\
\hline 11. & 4-Hydroxyproline & HYP & 0,3858 & 0,3012 & 0,4109 & 0,1796 & 0,7848 & 0,2285 & 0,4426 & 0,2087 & 0,5258 \\
\hline 12. & Glutamic acid & GLU & 6,765 & 8,4408 & 6,3516 & 5,8572 & 6,7915 & 5,2716 & 6,4516 & 9,4516 & 11,29 \\
\hline 13. & Phenylalanine & PHE & 1,2042 & 1,2537 & 1,3727 & 1,1893 & 1,1711 & 1,4536 & 1,5131 & 1,8137 & 1,7064 \\
\hline 14. & Lysine & LYS & 2,9618 & 2,4442 & 4,3082 & 3,2307 & 2,4179 & 2,5524 & 5,5639 & 3,7424 & 5,2131 \\
\hline 15. & Histidine & HIS & 0,5353 & 0,7183 & 1,173 & 0,9557 & 0,9263 & 0,8316 & 0,5896 & 2,2125 & 1,2474 \\
\hline 16. & Hydroxylysine & HYL & 0,3378 & 0,4 & 0,8404 & 0,3443 & 1,1 & 0 & 0,9497 & 1,56 & 0,2219 \\
\hline 17. & Tyrosine & TYR & 1,3444 & 1,3281 & 0,7301 & 1,4549 & 1,3752 & 0,7718 & 1,5292 & 2,3373 & 2,2213 \\
\hline 18. & Tryptophan & TRP & 0 & 0,5738 & 0 & 0,7393 & 1,4847 & 0,8353 & 0 & 1,4684 & 1,3315 \\
\hline 19. & Cystine & $C-C$ & 0,3222 & 0,3295 & 0,6058 & 0,563 & 0,4482 & 0,9959 & 0,6324 & 0,4301 & 0,321 \\
\hline 20. & & TOTAL & 27,15 & 30,95 & 34,38 & 27,23 & 29,58 & 29,58 & 35,58 & 43,97 & 43,14 \\
\hline
\end{tabular}

a negative way with the biochemical characteristics of ripening process and actually improves consumers' acceptability and water retention of soft brined cheeses.

\section{WSN content of experimental cheeses}

Our results indicate that WSN content is positively associated with ripening time and there was statistical significance associated with ripening time but show that WSN does not vary significantly within cheese treatment groups, thus suggesting that NSSO enrichment of cheese does not interfere with the ripening pattern. Similar findings are reported by McSweeney (29) and Cakir (33). Cakir (33) reported WSN values which increase significantly during ripening (until the end of ripening), for Tulum cheese. Another study revealed an increase in WSN, associated with a decrease in TN during ripening (34). Similarly, Özer (35) stated that WSN values in the Urfa cheese increased during the maturation period. They also stated that these values in the cheese produced from sheep milk were higher than those of the other types of milk at every stage of storage. Cais-Sokolin (36) also concludes that for mozzarella cheese, the amount of WSN is highly correlated with ripening extent. Tavaria (37) even reported that high WSN is obtained during the first three days after manufacturing of Serra da Estrela cheese.

\section{FAA content of experimental cheeses}

Bacterial peptidases release free amino acids (FAA) (secondary proteolysis), which contribute directly to the cheese flavor, but also indirectly through their metabolism by microbial amino acid converting enzymes, which is considered to be one of the main flavor pathways $(38,39)$. On the other hand, Sousa et all consider that a direct correlation between the concentration of FAA and cheese flavor cannot be established, since different types of cheeses have similar relative proportions of amino acids but differ distinctly in flavor (40).

Besides the controversial correlation between total FAA content of cheese and cheese flavor, there is general agreement to the fact that FAA may be considered a ripening index. For example, In a recent study (41), researchers investigated the effects of proteolytic enzyme supplementations to cheese milk on proteolysis characteristics of 90-day ripened cheese samples. They found that enzyme supplementations increased proteolysis and accelerated ripening and thus reduced ripening durations. In this study, total FAA contents of enzyme-supplement- 
ed cheeses were higher than the control cheese and the values increased in all cheese samples with the progress of ripening ( $p$ $<0.05$ ). Karaka (41) reported that the highest amino acids in all periods of ripening were identified as glutamic acid, lysine, proline and aspartic acid. Unlike the results communicated by Karaka (41), our study did not reveal statistical significance to total FAA increase during the 42 days of ripening considered for the experiment.

Our study revealed no qualitative variation of individual FAA during ripening and is therefore consistent with other studies, such as the one published by Innocente (25), who reports that the relative content of the individual FAA does not reflect the intensity of proteolysis, being more useful for the characterization of cheese. In addition, our results are consistent with those reported by Innocente (25), for one more reason, since this study also reports that it was not possible to determine the age of the studied cheese from its FAA content, even if the considered ripening time was longer (60 days) than the one used for our study.

On the contrary, there are studies which support the positive association between FAA total content and ripening period, such as the one published by Tavaria (37) which reported that FAA composition of Serra da Estrela cheese varied quantitatively, increasing with ripening time up to $3250 \mathrm{mg} / 100 \mathrm{~g}$. These increase rates are correlated with a much longer ripening period (180 days). However, unlike our findings, Tavaria (37) communicated that the greatest rate of increase in FAA was registered between 3 - 7 days following manufacture (21.7\%), while the major overall increase was observed between 18 - 35 days (174\%). Similarly, opposite findings related to our study results on total FAA, were revealed by the research of Cais-Sokolin (36), which reports that FAA content is highly correlated with smoking treatments applied for cheese ripening.

\section{Conclusions}

The purpose of this study was to investigate the effect of 0.2 and $1 \% \mathrm{w} / \mathrm{w}$ NSSO enrichment of raw milk, soft, brined cheese, over the ripening profile for 42 days. The TN content of analyzed cheeses did not show significant increase during ripening but revealed significant differences between the three considered treatment groups (control, 0.2 and 1\% w/w NSSO cheese). WSN values followed a significant rising shift in all cheeses during ripening, yet Computing data obtained for the three considered treatments, despite an obvious higher WSN content of NSSO enriched cheeses, no statistical significance could be associated to this difference. The FAA composition of the experimental cheeses, varied quantitatively, by increasing with ripening time, but no qualitative variation was noticed during the follow-up period. The FAA composition of the did not vary significantly within treatments. No statistical significance could be associated with the FAA rising shift variance during ripening, while the increasing rate difference between treatments was low and inconsistent with the amount of NSSO added to the cheeses.

These findings suggest that NSSO enrichment of cheese may not be a decisive factor for ripening acceleration and this may be the explanation for a lack of correlation between cheese treatments and total FAA content. Considering that the soft cheese included in our experiment is not a long-term ripened type of cheese, lack of positive association of NSSO enrichment with ripening acceleration is to be considered an advantage for application of NSSO enrichment, since it may be used for its antimicrobial properties, without interferences with the natural ripening process which characterizes this type of cheese.

\section{Conflict of interest statement}

The authors declare no conflict of interest.

\section{References}

1. Georgescu M, Dobrea M, Georgescu D. Microbial Population Dynamics in Presence of Lactococcal Bacteriophage During Ripening of Traditional Raw Milk Romanian, Agriculture and Agricultural Science Procedia, ELSEVIER, Volume 6, Pages 324-331, 2015.

2. Georgescu M, Savu C, Neagu I, Georgescu D. Coliform bacteria contamination profiling of raw milk cheeses using statistical assessment of type-linked correlations. AgroLife Scientific Journal - Volume 3, Number 2, 2014. Pag. 39-44, ISSN 2285-5718.

3. Nicolaescu M, Savu C. Assessment of ripening induced bacteriological changes in different Romanian traditional cheeses, Scientific works, Ministry of Education and Research, University of Agronomical Sciences and Veterinary Medicine, Bucharest, Faculty of Veterinary Medicine, C Series, XLIX, 2008, Bucharest, ISSN 1222-5304, 365-369, 2008.

4. Öner Z, Karahan AG, Aloglu H. Changes in the microbiological and chemical characteristics of an artisanal Turkish white cheese during ripening, Elsevier Science Direct, 2006. 39, 449-454.

5. Little CL, Rhoades JR, Sagoo SK, Harris J, Greenwood M, Mithani $V$ et al. Microbiological quality of retail cheeses made from raw, thermized or pasteurized milk in the UK. Food microbiology. 25. 304-12. 2008.

6. Choi KH. Cheese microbial risk assessments - A review. Asian-Australasian Journal of Animal Sciences, v.29, 307-314, 2016.

7. Prates Denise da Fontoura, Würfel SR, Goldbeck JC, Lima ASL, Graciela V, Silva WP. Microbiological quality and safety assessment in the production of moderate and high humidity cheeses. Ciência Rural, 47(11), 2017.

8. Bintsis T, Papademas P. Microbiological quality of white-brined cheeses: A review. International Journal of Dairy Technology. 55. $113-120.2002$.

9. Gao ML, Hou HM, Teng XX, Zhu YL, Hao HS, Zhang GL. Microbial diversity in raw milk and traditional fermented dairy products (Hurood cheese and Jueke) from Inner Mongolia, China. Genet Mol Res. 2017 Mar 8;16(1).

10. Eck A, Gillis JC. Cheese making - From science to quality assurance, second edition, translated by Gaelle Davies, Intercept Ltd., ISBN 1-898298-65-3; 2004.

11. Fox PF, Guinee TP, Cogan TM, McSweeney PLH. Fundamentals of cheese science, An Aspen Publication Inc., Gaithersburg, Maryland, USA, 2000. ISBN 0-8324-1260-9, p. 19-43, 206-278, 388-429, 484-514.

12. Fadavi A, Beglaryan R. Optimization of UF-Feta cheese preparation, enriched by peppermint extract. Journal of Food Science and Technology. 2015. 52(2):952-959.

13. Amatiste S, Sagrafoli D, Giacinti G, Rosa G, Carfora V, Marri N. Antimicrobial Activity of Essential Oils Against Staphylococcus aureus in Fresh Sheep Cheese. Italian Journal of Food Safety, 2014, 3(3), 1696.

14. El-Dahma MM, Khattab AA, Gouda E, El-Saadany KM, Ragab WA. 
The Antimicrobial Activity of Chitosan and Its Application on Kariesh Cheese Shelf Life. Alexandria Science Exchange Journal: An International Quarterly Journal of Science Agricultural Environments. 38. 733-745. 2017.

15. Wahba NM, Ahmed AS, Ebraheim ZZ. Antimicrobial effects of pepper, parsley, and dill and their roles in the microbiological quality enhancement of traditional Egyptian Kareish cheese. Foodborne Pathog Dis. 2010;7(4):411-8.

16. Gouvea FS, Rosenthal A, Ferreira EHR. Plant extract and essential oils added as antimicrobials to cheeses: a review. Ciência Rural, 2017. 47(8).

17. Alzahraa MID. Physicochemical Properties, Bioactive Compounds and Antioxidant Activity of Kareish Cheese Fortified with Spirulina platensis. World Journal of Dairy \& Food Sciences 12 (2): 71-78, 2017 ISSN 1817-308X.

18. Tarakci Z, Ekici K, Sagdic O, Kucukoner E. The effect of black cumin on ripening of Tulum cheese. Archiv fur Lebensmittelhygiene. 56. 135-139. 2005.

19. Alsawaf SD, Alnaemi HS. Effect of Nigella sativa (seed and oil) on the bacteriological quality of soft white cheese. Iraqi Journal of Veterinary Sciences, Vol. 25, No. 1, 2011, 21-27.

20. Hassanien MFR, Mahgoub SA, El-Zahar KM. Soft cheese supplemented with black cumin oil: Impact on food borne pathogens and quality during storage. Saudi Journal of Biological Sciences. 2014;21(3):280-288.

21. Mahgoub SA, Ramadan MF, El-Zahar KM. Cold Pressed Nigella sativa Oil Inhibits the Growth of Foodborne Pathogens and Improves the Quality of Domiati Cheese. Journal of Food Safety, 33: 470-480. 2013.

22. Cakir Y, Cakmakci S, Hayaloglu AA. The effect of addition of black cumin (Nigella sativa L.) and ripening period on proteolysis, sensory properties and volatile profiles of Erzincan Tulum (Şavak) cheese made from raw Akkaraman sheep's milk. In Small Ruminant Research, Volume 134, 2016, Pages 65-73, ISSN 0921-4488.

23. Georgescu M, Dobrea M, Tapaloaga D, Raita Ș, Dobrea V. Functional evaluation of Nigella sativa seed oil effect on pathogen enriched Artisan cheese. Journal of Biotechnology, 280 (2018): S54, Publisher Elsevier.

24. Georgescu D, Georgescu M, Tapaloaga D, Raita Ș. Sensory evaluation of experimental soft cheese enriched with Nigella sativa seed oil used as natural enhancer. Journal of Biotechnology, 280 (2018): S58, Publisher Elsevier.

25. Innocenten N. Free amino acids and water-soluble nitrogen as ripening indices in Montasio cheese. Le Lait, INRA Editions, 1997, 77 (3), pp.359-369.

26. Tăpăloagă D. 2013. Milk and meat processing technologies (in
Romanian). Granada, Bucharest 2013. p. 255-260. ISBN 978-6068254-33-3.

27. AOAC Official Method 33.7.12A - Determination of Nitrogen (Total) in cheese. Kjeldahl Method. AOAC International, 2003.

28. Kuchroo CN, Fox PF. Soluble nitrogen in Cheddar cheese: comparison of extraction procedures. Milchwissenschaftn. 1982 37:331335.

29. McSweeney PLH, Fox PF. Chemical methods for the characterization of proteolysis in cheese during ripening. Elsevier, Lait (1997) 77:41-76.

30. ANOVA version 9.1. SAS institute Inc., Cary, USA, 2003.

31. McSweeney PLH, Sousa, MJ. Biochemical pathways for the production of flavour compounds in cheeses during ripening: a review. Lait 2000, 80, 293-324.

32. Gobbetti M, De Angelis M, Di Cagno R, Rizzello C. "The relative contributions of starter cultures and non-starter bacteria to the flavour of cheese," in Improving the Flavor of Cheese, ed B. Weimer (Boca Raton, FL: Woodhead Publishing) 2007, 121-147.

33. Cakir Y, Cakmakci S. Some microbiological, physicochemical and ripening properties of Erzincan Tulum cheese produced with added black cumin (Nigella sativa L.). J Food Sci Technol. 2018 Apr;55(4):1435-1443.

34. Öner Z, Saridağ AM. Proteolysis in the Beyaz (White) Cheese Produced From Various Milk. Tarim Bilimleri Dergisi 2018. 24. 269277.

35. Özer B, Atasoy F, Akin S. Some properties of Urfa cheese (a traditional white-brined Turkish cheese) produced from bsheep and sheep milks. International Journal of Dairy Technology 2002, 55: 94-99.

36. Cais-Sokolinska D, Lasik A, Pikul J. Influence of water-soluble nitrogen and free amino groups on sensory attributes of smoked mozzarella cheese. International Journal of Food Properties, 2014. 17:1369-1378, 2014.

37. Tavaria FK, Franco I, Carballo FJ, Malcata FX (2003). Amino acid and soluble nitrogen evolution throughout ripening of Serra da Estrela cheese. International Dairy Journal 13(7): 537-545, 2003.

38. Ardö Y. Flavour formation by amino acid catabolism. Biotechnol. Adv 2006. 24, 238-242. doi: 10.1016/j.biotechadv.2005.11.005.

39. Yvon M. Key enzymes for flavour formation by lactic acid bacteria. Aust. J. Dairy Technol. 2006, 61, 88-96.

40. Sousa M, Ardö Y, Mcsweeney P. Advances in the study of proteolysis during cheese ripening. Int. Dairy J. 2001 11, 327-345.

41. Karaca OB, Güven M. Effects of Proteolytic and Lipolytic Enzyme Supplementations on Lipolysis and Proteolysis Characteristics of White Cheeses. Foods. 2018;7(8):125. 